\title{
ADJUDICATING WHAT YODER LEFT UNRESOLVED: RELIGIOUS RIGHTS FOR MINOR GHILDREN AFTER DANFORTH AND CAREY
}

\section{INTRODUCTION}

In Wisconsin $v$. Yoder, ${ }^{1}$ the Supreme Court held that a schoolattendance law requiring parents to send their children to school until the age of sixteen violated Amish parents' free exercise of religion, and infringed their right to direct the religious upbringing of their children. ${ }^{2}$ Over Justice Douglas' partial dissent, ${ }^{3}$ the Court limited its analysis to consideration of the constitutional rights of the parents as weighed against the state interest in requiring attendance in school, and specifically did not broach the subject of what constitutionally protected religious rights children might have distinct from those of their parents. ${ }^{4}$ The Court decided that it was unnecessary to consider the possible constitutional rights of the children because they were not parties to a prosecution of their parents for failure to send them to school. The case, moreover, did not involve any attempt by the parents to override their children's effort to attend school. ${ }^{5}$ Yoder, therefore, did not answer the ques-

1406 U.S. 205 (1972).

2 Id. 214.

3 [N]o analysis of religious-liberty claims can take place in a vacuum. If the parents in this case are allowed a religious exemption, the inevitable effect is to impose the parents' notions of religious duty upon their children. Where the child is mature enough to express potentially conflicting desires, it would be an invasion of the child's rights to permit such an imposition without canvassing his views. . . . As the child has no other effective forum, it is in this litigation that his rights should be considered. And, if an Amish child desires to attend high school, and is mature enough to have that desire respected the State may well be able to override the parents' religiously motivated objections.

Id. 242 (Douglas, J., dissenting).

4 [O]ur holding today in no degree depends on the assertion of the religious interest of the child as contrasted with that of the parents. It is the parents who are subject to prosecution here for failing to cause their children to attend school, and it is their right of free exercise, not that of their children, that must determine Wisconsin's power to impose criminal penalties on the parent. The dissent [by Justice Douglas] argues that a child who expresses a desire to attend public high school in conflict with the wishes of his parents should not be prevented from doing so. There is no reason for the Court to consider that point since it is not an issue in the case.

Id. 230-31.

5 The children are not parties to this litigation. The State has at no point tried this case on the theory that respondents were preventing their chil- 
tion what, if any, constitutionally protected religious rights children have apart from their parents' free exercise and child rearing rights. ${ }^{6}$ Nevertheless, Justice Douglas did suggest that the determination of children's religious rights can assume crucial importance, especially when the child's religious beliefs are at odds with his parents'

dren from attending school against their expressed desires, and indeed the record is to the contrary. The State's position from the outset has been that it is empowered to apply its compulsory-attendance law to Amish parents in the same manner as to other parents-that is, without regard to the wishes of the child. That is the claim we reject today.

Our holding in no way determines the proper resolution of possible competing interests of parents, children, and the State in an appropriate state court proceeding in which the power of the State is asserted on the theory that Amish parents are preventing their minor children from attending high school despite their expressed desires to the contrary. Recognition of the claim of the State in such a proceeding would, of course, call into question traditional concepts of parental control over the religious upbringing and education of their minor children recognized in this Court's past decisions. It is clear that such an intrusion by a State into family decisions in the area of religious training would give rise to grave questions of religious freedom comparable to those raised here and those presented in Pierce v. Society of Sisters, 268 U.S. 510 (1925). On this record we neither reach nor decide those issues.

\section{Id. 231-32 (footnote omitted).}

6 The Yoder majority is correct in saying that the case could be limited to balancing parental rights against state interests without looking to any constitutional rights the children might possess. There was no evidence in the record suggesting that the children disagreed with their parents. What evidence there was suggested that they too felt their religious beliefs would be compromised by school attendance. Because Yoder held only that the parents could not be compelled to send their children to school, any weight that might have been added on the side of the parents by considering the children's independent right not to go to school would have been superfluous. But assume instead that the children did not consider themselves Amish and wanted to go to public school. Nothing in Yoder prevents the children from going to school; Yoder holds only that the state cannot force the parents to send their children to school.

If the parents dissuade or restrain the children from going to school, and thus force their Amish beliefs on their offspring, there is no violation of the children's constitutional rights. Even if children possess free exercise rights against state interference, these rights do not protect them from the private interference of their parents. See notes 6, 114, 134-36 \& accompanying text infra. As the majority suggests, however, the children might then call upon the state for assistance "in an appropriate state court proceeding," 406 U.S. at 23I, and prevent their parents from restraining them from going to school. Perhaps it would be decided that, although Yoder on its facts prevents the state from forcing parents under penalty of law to send their children to school, the newly-added interest of the children in being free from parental imposition of religious beliefs contrary to their own enables the state to prevent the parents from physically restraining their children from attending school. Therefore, although Justice Douglas rightly asserts that it might have been procedurally fairer to have investigated the children's interests in Yoder rather than to have put the onus on them to start a new proceeding in the event their parents restrain them from going to school, see id. 244-46, the failure to consider these possible interests of the children and the exemption of their parents from the strictures of the school-attendance laws do not infringe on any constitutional right of the children to be free from state interference with their religious beliefs. 
religious preferences, and the government is involved in such a way as to trigger a constitutional controversy. ${ }^{7}$

7 Assuming that the source of children's religious rights is the first amendment's free exercise clause, state action is required before any interference with children's religious liberty presents a constitutional problem. See, e.g., Hudgens v. NLRB, 424 U.S. 507 (1976). For cases evidencing the contours of the state action requirement in a context other than the first amendment, see Jackson v. Metropolitan Edison Co., 419 U.S. 345 (1974); Moose Lodge No. 107 v. Irvis, 407 U.S. 163 (1972); Burton v. Wilmington Parking Authority, 365 U.S. 715 (1961). It is, therefore, crucial to differentiate between a child's liberty interest, e.g. his interest in being free of parental interference with his religious choices, and the child's constitutional immunity to government infringement of his free exercise right. The extent to which the state should, or indeed could, grant protection to juveniles against their parents' or others' interference with their free exercise right is outside the scope of this Comment.

Determining when the state is involved is of course a question not yet graced with a precise answer. Compare Reitman v. Mulkey, 387 U.S. 369 (1967), with Jackson v. Metropolitan Edison Co., 419 U.S. 345 (1974). See generally Comment, State Action: Theories for Applying Constitutional Restrictions to Private Activity, 74 ColUM. L. REv. 659 (1974). One commentator suggests that the pervasiveness of law recognizing parental authority over children might be regarded as translating into state action any restriction placed by a parent on his child. Burt, Developing Constitutional Rights of, in, and for Children, 39 L. \& ConTzMr. ProB. 118, 137 (Summer 1975). A related but somewhat less fanciful argument is that in certain cases the failure of the state to act to protect the interest of the child is state action. For instance, Justice Douglas, dissenting in part in Yoder, seems to suggest that the state's failure to prevent parents who restrain their children from going to school from imposing their religious belief upon their children might impinge upon the children's constitutional rights.

If the parents in this case are allowed a religious exemption, the inevitable effect is to impose the parents' notions of religious duty upon their children. Where the child is mature enough to express potentially conflicting desires, it would be an invasion of the child's rights to permit such an imposition without convassing his views.

406 U.S. at 242. See also Tribe, Childhood, Suspect Classifications, and Conclusive Presumptions: Three Linked Riddles, 39 L. \& ContenI. Proв. 8, 12 n.13 (Summer 1975):

[W] hen a family is in disintegration or at the threshold of collapse or when an adolescent persistently seeks complete emancipation and is willing, in return to relieve his or her parents of reciprocal obligations, then it seems wrong to exonerate the state of responsibility for such coercive parental measures as it permits even by its inaction.

Conversely, it has been suggested that when the state is in fact acting there may sometimes be no state action.

[A]ssociational considerations help to establish the boundaries of "state action" concept in the first instance. See Henkin, Shelley v. Kraemer:

Notes for a Revised Opinion, 110 U. PA. L. Rev. 473 (1962). Thus, routine cases of parental discipline in an essentially successful family whose continuation is mutually desired will properly be treated as raising no real constitutional issue even when the state extends various forms of incidental support to parental authority; in these cases the state simply should not be deemed responsible for how such authority is exercised, with the result that constitutional constraints will not apply.

Id.

Finally, it should be noted that not all constitutional rights are protected against government alone. The thirteenth amendment's prohibition against slavery is mandatory upon private individuals as well as government. Although it would be absurd to apply the thirteenth amendment to the ordinary relationship between 
Although some earlier cases recognized substantive rights of juveniles, ${ }^{8}$ it was not until Planned Parenthood $v$. Danforth ${ }^{9}$ that the Supreme Court held that minors have constitutionally protected rights distinct from the rights of their parents. Danforth held that a statute giving parents an absolute veto over a minor's abortion decision violated her constitutionally protected privacy rights. The importance of this holding to any discussion of juveniles' constitutional rights is obvious: if minors possess privacy rights that cannot be constitutionally delegated, even to parents, they almost certainly independently possess other substantive rights. Specifically, if children are deemed to possess independent privacy rights, is there any reason not to recognize constitutionally protected religious rights of children, even in the absence of parental support for these beliefs, or even in the face of active parental hostility?

If Danforth can be read to extend the blessings of the first amendment, as well as the privacy right, to juveniles, Yoder becomes as notable for the questions it has left unanswered as for the question it did address. What if the children in Yoder continue to go to public school against their parents' will? Could the school deny them entrance? May a child object, on religious grounds, to attendence in a sectarian school in which he has been enrolled by his parents? If he does, and is truant, or runs away, may his parents enlist the aid of the state in securing his submission? ${ }^{10}$ Alternatively, may avowedly secular parents obtain state assistance in detaching their child from a fundamentalist group or mystical sect? ${ }^{11}$

parent and child, in an extreme case perhaps this amendment could become applicable. "Once a person is capable of survival away from home and insists, after sustained reflection, upon a complete break, to permit his or her parents to hold on arguably shares most of the characteristics of enslavement rather than those of voluntary association." Id. See also note 101 infra.

8 See text accompanying notes 55-63 infra.

9428 U.S. 52 (1976).

10 See, e.g., CAL. WELF. \& INST. CODE $\$ 601$ (West 1972): ("Any person under the age of 18 years who persistently or habitually refuses to obey the reasonable and proper orders or directives of his parents . . . or who is beyond the control of such person ... is within the jurisdiction of the juvenile court which may adjudge such a person to be a ward of the court."); N.J. STAx. ANN. \$2A:4-45 (West Supp. 1977); Orno Rev. Cone ANN. \$2151.022 (Page 1976).

11 Recently, certain religious groups have sought to detach children from their parents. They are not altogether without religious authority in this effort. See, e.g., Luke 14:26 (King James): "If any man come to me, and hate not his father, and mother . . . he cannot be my disciple." This religiously based splintering of the famliy unit raises interesting legal issues, but the cases so far have dealt with adult children, and the parents interest in child-rearing, therefore, has not been fully tested. See, e.g., Schuppin v. Unification Church, 435 F. Supp. 603 (D.C. Vt. 1977). 
What result in "medical cases" when the child's religious attitudes toward blood transfusions or surgery clash with those of his parents? ${ }^{12}$ What weight should be accorded the child's religious preference if religion is a major issue in a custody battle? ${ }^{13}$ If these questions involve two distinct constitutional rights-a free exercise right of the child and a free exercise-child raising right of the parent-can the state ever attempt to provide an answer without violating the Constitution?

This Comment will explore the contours of intra-family free exercise conflicts in the light of Yoder and Danforth. First it will examine the history and present status of the parental right to supervise religious upbringing. Next it will turn to the questions of the existence, nature and scope of a right of freedom of religion for minors. Finally it will suggest what accommodation is possible if both rights are to be respected and the state is to avoid the difficult, undesirable, and almost certainly unconstitutional regulation of matters of family and religious conscience.

\section{The Parental Interest in the Child's Religious Upbringing}

\section{A. At Common Law}

There has been a remarkable historical evolution in the rights of parents to determine the upbringing of their children. Midsixteenth century English history is largely centered on the struggle between an emerging Protestantism and the older Roman Catholic order. ${ }^{14}$ During the reign of Elizabeth, the Protestants gained the ascendency, and one of the Elizabethan reforms was the passage of repressive religious statutes. ${ }^{15}$ Aimed at securing the triumph of Protestantism, these enactments circumscribed the authority of parents to direct the religious upbringing of their children.

Many of the statutes sought to accomplish this by interfering with the ability of Roman Catholic parents to educate their children in Roman Catholic schools. In 1590, the Elizabethans enacted a statute requiring schoolmasters to adhere to the Established

12 These cases can arise when either parent or child is a Christian Scientist or Jehovah's Witness, perhaps the two best known religious groups opposed to certain medical practices. For a discussion of the conflicts possible in these cases, see text accompanying notes $111-15,147-51$ infra.

13 Custody cases involving religious issues are not uncommon, and the views of the child are often taken into account. See generally text accompanying notes 106-10, 152 infra.

14 See Friedman, The Parental Right to Control the Religious Education of a Child, 29 Harv. L. Rev. 485 (1916).

16 Id. 485 . 
church. ${ }^{16}$ In the years which followed, this measure was supplemented by another enactment which made it a crime for a Roman Catholic parent to send his child abroad for a Catholic education; another law imposed perpetual imprisonment on any Roman Catholic who maintained a school or otherwise sought to educate young people. ${ }^{17}$

The eighteenth century saw a gradual relaxation of these strictures, as Protestantism became more entrenched and secure. ${ }^{18} \mathrm{Al}-$ though the statutes themselves remained on the books, they began to be given a more liberal interpretation. ${ }^{19}$ By the early 1800 's the English bench was quite willing to look with equal favor on all religions in family matters. ${ }^{20}$ Thus, the state's control over religious upbringing was gradually loosened, and was replaced by rules of law that vested control in the father. ${ }^{21}$ This doctrine of religio sequitur patrem is illustrated by the words of the judge in In re Newton: ${ }^{22}$

In no case ... that I am aware of, where the father has been alive, has the court disregarded his wishes concerning the religious education of his children, unless ... he has been himself a man so ill-conditioned and of such bad conduct that the court thought fit altogether to deprive him of the custody of his children. ${ }^{23}$

The rationale for the rule lay simply in the fact that "the father is the head of the household, exercising the absolute right and under-

$16 I d$.

17 Id. Nor were Roman Catholic parents always trusted in their own homes. Thus in Teynham v. Lennard, 4 Bro. P.C. 302, 2 Eng. Rep. 204 (1724), the Lord Chancellor, complying with the request of the paternal grandfather of a seven-yearold child, ordered that a Roman Catholic widow be denied custody of her child. Although the mother was raising him as a Protestant in accordance with the wishes of her late husband, the Chancellor feared that the "Papist" mother might instill "the principles of that religion into the infant," and thus gave custody to a person recommended by the grandfather.

18 Friedman, supra note 14, at 487.

10 Blackstone was able to write in 1765 :

[W] hat foreigners who only judge from our statute-book are not fully apprized of [is] that these laws are seldom exerted to their utmost rigor: and, indeed if they were, it would be very difficult to excuse them. For they are rather to be accounted for from their history, and the urgency of the times which produced them, then to be approved ... as a standing system of law.

4 W. Blackstone, Comarentaries "57.

${ }^{20}$ See, e.g., Lyons v. Blenkin, Jac. 245, 37 Eng. Rep. 842 (1821).

21 Friedman, supra note 14, at 488-89.

22 L.R. 1 Ch. 740 (1865).

23 Id. 748. 
taking the responsibility nature gave him through the birth of the child, for the interest of the child, the family and the public welfare." 24 It was an inflexible rule and its application often brought about absurd results. ${ }^{25}$ But it was a convenient rule as well, and it remained in full force in England until the passage of the Guardianship of Infants Act of 1925.28 That act abrogated the common law rule, and with its passage courts were instructed to decide family matters involving children with "the welfare of the infant as the first and paramount consideration." 27

Although the Guardianship of Infants Act changed the legal standard to be applied in cases involving the religious beliefs of children, the result was often the same as under the doctrine of religio sequitur patrem, for the courts assumed that the "best interest of the child" would be effectuated by vindicating the religious views of the father without consideration of the child's religious preferences. Thus in Todd $v$. Lyons, ${ }^{28}$ the Vice Chancellor ordered the superior of a monastery to refrain from admitting a young man of seventeen to monastic vows against the father's consent, and ordered that the minor be delivered back to the father immediately. In a second English case, Iredell $v$. Iredell, ${ }^{29}$ decided in 1885 , the court granted an injunction restraining certain persons from further communicating with a young girl. It appears that they had been surreptitiously meeting with her, trying to convince her to abandon her rather's religion in favor of theirs. ${ }^{30}$

In the United States, government has never compelled parents to educate their children according to the tenets of any particular faith, as had once been the case in England.31 Although some

24 Comment, Parents' Right to Prescribe Religious Education of Children, 3 De PAUL L. Rev. 83, 84 (1953).

25 Thus, except where the father had forfeited control, it was preserved even after his death, and courts were not hesistant to force a widowed mother to raise her children according to a religion contrary to her own. See Hawksworth v. Hawksworth, L.R. 6 Ch. 539, 539-40 (1871).

26 Where in any proceeding before any court . . . the custody or upbringing of an infant . . . is in question, the court, in deciding that question, shall regard the welfare of the infant as the first and paramount consideration, and shall not take into consideration . . . the claim of the father, or any right at common law possessed by the father . . . superior to that of the mother. . . .

Guardianship of Infants Act, 1925, I5 \& 16 Geo. 5, c.45, $§ 1$.

27 Id.

28 Unreported. See Friedman, supra note 14, at $497 \& \mathrm{n} .43$.

291 Times L.R. 260 ( 1885 ).

30 Id. 261.

31 See Friedman, supra note 14, at 497. 
jurisdictions have followed the religio sequitur partrem doctrine, ${ }^{32}$ most American jurisdictions adopted instead the "best interest of the child" standard of the Guardianship Act. ${ }^{33}$

As was the practice in England, however, it has been all but an irrebuttable presumption that the best interest of the child was most effectively accomplished by upholding the father's preferences for religious upbringing without regard to the child's preference in the matter. Thus the "best interest" standard in religious matters was often indistinguishable in the United States from religio sequitur patrem. ${ }^{34}$ Moreover, when the courts did intervene in the religious affairs of minors it was most often to prevent an "officious intermeddler" from interfering with parental authority. Thus in Prieto v. St. Alphonsus Convent of Mercy, ${ }^{35}$ the Supreme Court of Louisiana ordered a convent to expel a seventeen-year-old girl who had entered it to become a nun. The girl's widowed mother had never consented to her daughter's decision, and now adamantly objected. In sustaining the writ of habeas corpus brought by the mother, the court did not consider the daughter's religious preferences, and did not raise the possibility that the daughter had any independent right to exercise her religious beliefs.

Even when, under the "best interest" standard, the parents' child-rearing preferences in the area of religion occasionally were held not to control, the "best interest" approach to resolving religious questions concerning children did not include considerations of the child's own religious preferences. ${ }^{36}$

32 In an early New York case, a guardian was ordered to raise his ward according to the religious beliefs of the natural father even though those beliefs were inconsistent with the guardian's religious beliefs.

33 See Boerger v. Boerger, 26 N.J. Super. 90, 97 A.2d 419 (Ch. Div. 1953); Cory v. Cory, 70 Cal. App. $2 d$ 563, 161 P.2d 385 (1945); Purinton v. Jamrock, 195 Mass. 187, 80 N.E. 802 (1907).

34 See Friedman, supra note 14, at 498-99.

The "best interests of the child" were also beginning to be protected in other areas of the law by the late $1800^{\prime} \mathrm{s}$, and in these areas the needs of the child were receiving greater protection. The first child abuse case, for example, was reported in New York City in 1875. See, Grumet, The Plaintive Plaintiffs: Victims of the Battered Child Syndrome, in The Youngest Minorury (S. Katz ed. 1974).

3552 La. Ann. 631, 27 So. 153 (1900).

${ }^{36}$ See, e.g., Purinton v. Jamrock, 195 Mass. 187, 80 N.E. 802 (1907), where the mother of an illegitimate child attempted to block an adoption order that would have awarded the child to adoptive parents of a different religious faith. The court, while recognizing that children should be placed with adoptive parents of the same religious faith when "reasonably practicable," stressed that its paramount duty was to consult "the welfare of the child." Id. at 199-200, 80 N.E. at 804-05. In this case, the "best interests" required that the child be given over to the adoptive parents despite the fact that they were of a different religious faith. 


\section{B. Constitutional Protection}

By a series of Supreme Court decisions, the common law right of parents to direct their children's upbringing has been enshrined as a constitutional right. In Pierce $v$. Society of Sisters, ${ }^{37}$ the Supreme Court held that the liberty element of the fourteenth amendment's due process clause includes "the liberty of parents ... to direct the upbringing and education of children under their control" and that an Oregon law requiring every child to attend public school violated that right. ${ }^{38}$ Although the Court spoke of parental rights generally and did not specifically address parents' rights to oversee their children's religious development, the ultimate issue in the case was the right of parents to send their children to a Roman Catholic school in lieu of public school. ${ }^{39}$ In Prince $v$.

37268 U.S. 510 (1925).

38 Id. 534-35. Two years earlier in Meyer v. Nebraska, 262 U.S. 390 (1923), the Court had held a statute forbidding the teaching of the German language to young children violative of the fourteenth amendment, declaring:

Without doubt, . . . [liberty] denotes not merely freedom from bodily restraint but also the right of the individual to contract, to engage in any of the common occupations of life, to acquire useful knowledge, to marry, establish a home and bring up children, to worship God according to the dictates of his own conscience, and generally to enjoy those privileges long recognized at common law as essential to the orderly pursuit of happiness by free men.

Id. 399.

In the years following Meyer and Pierce, the Court repudiated the substantive due process analysis on which those cases were based, see Day-Brite Lighting, Inc. v. Missouri, 342 U.S. $421,423,425$ (1952); Olsen v. Nebraska, 313 U.S. 236, 245-47 (1941); McCloskey, Economic Due Process and the Supreme Court: An Exhumation and Reburial in Amrertcan Constrtutronar Law 155 (L. Levy ed. 1966), but their spirit lived on and they were both reinterpreted in Griswold v. Connecticut, 381 U.S. 479 (1965), as first amendment cases. Griswold found unconstitutional a Connecticut statute which made it unlawful to use contraceptives. In discussing prior cases that had delineated the parameters of the constitutional provisions involved in the instant case, the Court, per Justice Douglas, ascribed "[t]he right to educate a child in a school of the parents' choice" to the first amendment. Id. 482. Justice Stewart, dissenting in the Court's earlier decision in Abington'S School District v. Schempp, 374 U.S. 203, 312 (1963), had argued that "[i]t has become accepted that the decision in Pierce . . . upholding the right of parents to send their children to nonpublic schools, was ultimately based upon the recognition of the validity of the free exercise claim involved in that situation."

${ }^{39}$ Although the law in question made it a misdemeanor for parents to fail to send their children to public school, the suit was brought by a Catholic school, 268 U.S. at 530-32. The Court held that the mandatory public school attendance was an "arbitrary, unreasonable, and unlawful interference with [the school's] business and property." Id. 536. "The school had alleged that the law infringes upon "the right of parents to choose schools where their children will receive appropriate mental and religious training." Id. 532. The school argued in part: "In this day and under our civilization the child of man is his parents' child and not the State's. . . It is not seriously debatable that the parental right to guide one's child intellectually and religiously is a most substantial part of the liberty of the parent." Id. 518 (argument of appellant). 
Massachusetts, ${ }^{40}$ although upholding the power of the state to prevent a guardian from allowing a child under her control to distribute religious literature, ${ }^{41}$ the Court recognized the constitutional rights of "parents to give [children] religious training and to encourage them in the practice of religious belief." 42

When the Court confronted the claims of the Amish parents in Wisconsin $v$. Yoder, ${ }^{43}$ it took the opportunity to restate and support this view. Although the parents did not object to elementary education, they believed that sending their children to high school would expose the children to worldly ways and thereby endanger their own and their children's salvation. ${ }^{44}$ In freeing the parents from that part of the Wisconsin compulsory education law requiring them to send their children to school beyond the eighth grade, the Supreme Court read Pierce as "a charter of the rights of parents to direct the religious upbringing of their children." 45 Chief Justice Burger announced that the case involved "the fundamental interest of parents, as contrasted with that of the State, to guide the religious future and education of their children." ${ }^{46}$ He then went on to declare that "the history and culture of Western civilization reflect a strong tradition of parental concern for the nurture and upbringing of their children. This primary role of the parents in the upbringing of their children is now established beyond debate as an enduring American tradition." 47 Thus, where "nothing more than the general interest of the parent in the nurture and education of his children is involved," the Court would allow the state to intervene if the intervention were reasonably likely to foster the child's health, safety or welfare. ${ }^{48}$ Where, however, "the interests of parenthood are combined with a free exercise claim," 40 more than just a "reasonable relation to some purpose within the competency of the state" would be required to justify intrusion by the state. ${ }^{50}$ Only when it appeared that parental decisions would "jeopardize the health or safety of the child, or have a potential for

40321 U.S. 158 (1944).

41 Id. 170 .

$42 I d .165$.

43406 U.S. 205 (1972).

44 Id. 209.

$45 \mathrm{Id} .233$.

40 Id. 232.

47 Id.

48 Id. 233.

49 Id.

50 Id., quoting Pierce v. Society of Sisters, 268 U.S. 510, 535 (1925). 
significant social burdens," would the power of the parent, linked to a free exercise claim, be subject to limitation under Prince. ${ }^{51}$

When viewed with the common law's acceptance of parental control over the child's religious indoctrination, ${ }^{52}$ the Yoder holding, with its interpretation of the line of cases from Pierce through Prince, might be read as establishing that the first amendment's free exercise provisions vest in the parents a constitutionally-protected right to direct their child's religious upbringing in the absence of any compelling reason for state interference. 53 Thus the common law standard of "best interest of the child," with its presumption that those interests can best be served without governmental interference, has been incorporated in the first and fourteenth amendments, with the result that the state may not circumscribe parental discretion in religious matters unless some palpable harm would otherwise befall the child. ${ }^{54}$

\section{Towards Constitutionaliy Protected Religious Rights OF GHILDREN}

\section{A. Rights Emerging}

Although there is language in Prince $v$. Massachusetts ${ }^{50}$ that suggests children have constitutional religious rights, the Supreme Court has never held that these rights are anything more than an aspect of the religious liberty of parents. Thus Pierce, Prince and Yoder cannot be read as recognizing that children have religious rights distinct from their parents' religious rights. On the other hand, these cases do not stand for the proposition that such an independent right does not exist. In Pierce the issue of the children's

51 Id. 234.

62 See text accompanying notes 22-34 supra.

53 It should also be noted that the parents' interest in the religious upbringing of their children has been implicitly recognized in a number of the establishment clause cases brought by parents seeking to bar religious instruction in public schools attended by their child. See Engel v. Vitale, 370 U.S. 421 (1962); McCollum v. Board of Education, 333 U.S. 203 (1948).

54 Even before Yoder some courts had read Pierce, Prince or the common law effectively to establish a constitutional right of parents to direct their children's religious upbringing. See, e.g., In re Guardianship of Faust, 239 Miss. 299, 123 So. $2 d 218$ (1960). In that case the Mississippi Supreme Court reversed a chancery court decree that had ordered the father of two teenage boys to leave them in a public school and to permit them to attend the church of their own choice.

55321 U.S. 158, 165-66 (1944). The Court noted that the right of children to exercise their religion had been recognized in West Virginia State Bd. of Educ. v. Barnette, 319 U.S. 624 (1943), and that the child's right to receive religious training as having been sustained in Pierce v. Society of Sisters, 268 U.S. 510 (1925). Barnette upheld a religiously-based refusal of public school children to salute the flag. 
religious beliefs was passed over by the Court. ${ }^{58}$ In Prince the child testified that her religious beliefs were in accord with those of her guardian. ${ }^{57}$ And in Yoder the Court avoided the issue by declaring that the parents' constitutional rights alone were sufficient to outweigh the state's interest. ${ }^{.8}$ In none of these cases was the specification of the child's religious preference a necessary element of the adjudication, nor was there any indication that the views of the children were not in accord with their parents' religious preferences.

That the Court's emphasis in these cases should be on the parental rights is understandable, for it was the parents who were subject to prosecution. But an examination of the cases in which the issue of children's constitutional rights came to the fore reveals a similar ambiguity between juvenile and parental rights. Indeed, in no case before Danforth did the Supreme Court explicitly hold that juveniles have substantive rights independent of their parents. ${ }^{59}$

Thus, in Tinker $v$. Des Moines Independent Community School District, ${ }^{80}$ which held that public schools unduly infringed

56 The school had argued that the statute, inter alia, infringed the "right of the child to influence the parents' choice of a [religious] school," 268 U.S. at 532, but the Court did not address this argument.

57321 U.S. at 162-63.

58406 U.S. at 230-31. One of the children, however, did testify that her religious beliefs were in accord with those of her parents. Id. $231 \mathrm{n.21}$.

59 In the procedural arena, however, the Supreme Court has maintained that juveniles have considerable rights. In In re Gault, 387 U.S. 1, 30 (1967), the Court held that juveniles in the adjudicatory stage of delinquency proceedings that may lead to commitment to a state institution must be guaranteed the constitutional rights of notice, counsel, confrontation and cross examination of witnesses, as well as the privilege against self-incrimination. Subsequently, in In re Winship, 397 U.S. 358 (1970), the requirement of proof beyond a reasonable doubt was extended to such juvenile adjudication. Recently, the prohibition against double jeopardy, Breed v. Jones, 421 U.S. 519 (1975), and procedural due process in a civil context, Gross v. Lopez, 419 U.S. 565 (1975), were made applicable to juveniles. See also Gallegos v. Colorado, 370 U.S. 49 (1962) (extending the protection against coerced confessions to juveniles); Haley v. Ohio, 332 U.S. 596 (1948). But see Ingraham v. Wright, 430 U.S. 651 (1977), holding that although corporal punishment of students in public schools implicates "a constitutionally protected liberty interest," no further process is due beyond the presently available state law remedies. Id. 672 .

It is interesting to note that even in the procedural sphere it is not clear that the child's right is distinct from that of his parents, and if so just where the distinction lies. For example, in recognizing procedural rights for juveniles in Gault, the Court appeared to be protecting the interests of the parents in the "Iiberty" of the child in addition to the interests of the child himself. Thus, the Court in Gault stressed that the rights to notice and counsel belonged to both parent and child, because the parent's custody of the child was also at stake. In re Gault, 387 U.S. 1, 41-42 (1967).

60393 U.S. 503 (1969). Note that the parents brought the suit on behalf of their children. Id. 504. For a case in which a child brought suit against the school board over the opposition of his parents, see Buckholz v. Leveille, 37 Mich. App. 166, 194 N.W.2d 427 (1971). 
upon students' first amendment rights by disciplining them for wearing black armbands in protest against the Vietnam War, the Court noted the existence of parental consent to the wearing of black armbands. In Ginsberg $v$. New York, ${ }^{61}$ in upholding a law that banned the sale of obscene literature to children-literature that clearly could not have been considered obscene for adults 62 -the Court justified this lesser first amendment protection given juveniles on the ground that the state was vindicating the parents' interest in determining their children's reading material. ${ }^{63}$

On the other hand, in discussing these substantive rights the Court often focused on the deprivation of the rights of the children themselves. Thus, in Tinker the Court declared that "[s]tudents in school as well as out of school are 'persons' under our Constitution. They are possessed of fundamental rights which the State must respect, just as they themselves must respect their obligations to the State." ${ }^{64}$ More recently, in Goss $v$. Lopez, ${ }^{65}$ which required that a child be given a due process hearing before he can be suspended from school, the Court discussed the child's substantive rights that the hearing would protect:

[Suspension] is a serious event in the life of the suspended child. Neither the property interest in educational benefits temporarily denied nor the liberty interest in reputation, which is also implicated, is so insubstantial that suspensions may constitutionally be imposed by any procedure the school chooses, no matter how arbitrary. ${ }^{66}$

\section{B. Children's Independent Privacy Rights}

It would be idle to argue that these cases establish an independent free exercise right for children whose parents actively oppose their religious preferences. However, two recent Supreme

61390 U.S. 629 (1968).

62 Id. 634-35.

${ }^{63}$ Id. 639.

64393 U.S. at 511.

65419 U.S. 565 (1975).

66 Id. 576 (footnote omitted). But see Ingraham v. Wright, 430 U.S. $65 I$ (1977) (paddling of students in public school as corporal punishment not violative of eighth amendment prohibition against Cruel and Unusual punishment, even if punishment is so excessive as to severely injure the child).

Substantive constitutional interests have also been recognized by lower courts when a parent attempts to commit the child to a mental institution against the child's will. See J. L. v. Parham, 412 F. Supp. 112 (M.D. Ga. 1976), prob. juris. noted, 431 U.S. 936 (1977); Bartley v. Kremens, 402 F. Supp. 1939 (E.D. Pa. 1975), prob. juris. noted, 424 U.S. 964 (1976), dismissed as moot, - U.S. (1977). See also Anderson v. Laird, 466 F.2d 283 (D.C. Cir.), cert. denied, 
Court cases, Planned Parenthood v. Danforth ${ }^{67}$ and Carey v. Population Services International, ${ }^{68}$ do lend support to such an argument. In Danforth, the Court was asked to test the constitutionality of a Missouri statute that, as part of a complex scheme of abortion regulation, imposed "a blanket provision ... requiring the consent of a parent or person in loco parentis as a condition for abortion of an unmarried minor during the first twelve weeks of her pregnancy." ${ }^{0}$ In striking down the provision the Court declared, "[c]onstitutional rights do not mature and come into being magically only when one attains the state-defined age of majority. Minors, as well as adults, are protected by the Constitution and possess constitutional rights." 70 The Court concluded that "the State does not have the constitutional authority to give a third party an absolute, and possibly arbitrary, veto" over a minor's constitutionally protected privacy right to make the abortion decision in consultation with her physician. ${ }^{71}$

The Court rejected both the district court's view that there was a "compelling basis" for the statute in the state's interest "in safeguarding the authority of the family relationship," 72 and the state's argument that the statute vindicated the parental right to direct the upbringing of the child. The state had urged that the law "properly may subject minors to more stringent limitations than are permissible with respect to adults," especially where the limitations are on decisions that "are outside the scope of a minor's ability

409 U.S. 1076 (1972), in which the Court of Appeals for the District of Columbia Circuit voided the mandatory chapel attendance rules of federal military academies. With one circuit judge dissenting, the court held that the regulations were invalid under the establishment clause, with Chief Judge Bazelon stating that the regulations also violated the student's free exercise rights. The plaintiffs here were not parents of students, but the students themselves. Id. 284. The regulations, while permitting a cadet or midshipman to be excused for conscientious objection to church or chapel attendance, were otherwise unequivocal, id. nn.3 \& 5, and permitted the student to change his regular attendance only after he had received permission from "the respective chaplains involved and from his parents if he [was] under twenty-one." Id. 284. In reaching its conclusion on the establishment issue, the court effectively extended the first amendment's religious guarantees to minors who were manifesting their preferences independently of their parents. Thus, there can be no asserting that the court in this instance was adjudicating the parent's rights on behalf of the children. The decision did, however, rest on establishment rather than free exercise grounds.

67428 U.S. 52 (1976).

68431 U.S. 678 (1977).

69428 U.S. at 74 .

$70 \mathrm{Id}$. (footnotes omitted).

71 Id. The constitutionally protected privacy right in the abortion context was recognized in Roe v. Wade, 410 U.S. 113 (1973) and Doe v. Bolton, 410 U.S. 179 (1973).

72 Planned Parenthood v. Danforth, 352 F. Supp. 1362, 1370 (E.D. Mo. 1975). 
to act in his own best interest." 73 The state had also argued that it was proper to delegate the authority to make those decisions to the parents in light of the Court's previous recognition of parental discretion in child raising. ${ }^{74}$ The Court was unpersuaded, however, finding it "difficult ... to conclude that providing a parent with absolute power to overrule a determination, made by the physician and his minor patient, to terminate the patient's pregnancy. will serve to strengthen the family unit." 75 The Court also found it unlikely that such veto power would "enhance parental authority or control where the minor and the nonconsenting parent are so fundamentally in conflict and the very existence of the pregnancy already has fractured the family structure." 76 If the parent had any independent interest in preventing the termination of the minor daughter's pregnancy, it is "no more weighty than the right of privacy of the competent minor mature enough to have become pregnant." 77

Having determined that a privacy right for minors exists distinct from parental rights, and, at least to some extent, that it may be exercised independent of parental permission, the Danforth Court went on to address the scope of that right. The primary fault with Missouri's parental consent requirement was that it gave "a third party an absolute, and possibly arbitrary, veto" over the minor's decision without sufficient justification. ${ }^{78}$ The Court stressed that its holding did not intend that "every minor, regardless of age or maturity, may give effective consent for termination of her pregnancy." 70

In a concurring opinion, in which he argued that the statute's "primary constitutional deficiency [lay] in its imposition of an absolute limitation on the minor's right to obtain an abortion," 80 Justice Stewart emphasized the limited scope of the holding:

[A] materially different constitutional issue would be presented under a provision requiring parental consent or consultation ... but providing for prompt . . . judicial resolution of any disagreement between the parent and the minor, or ... judicial determination that the minor is mature enough to give an informed consent without

73428 U.S. at 72.

74 Id. 73.

75 Id. 75.

$70 \mathrm{Id}$.

77 Id.

78 Id. 74.

79 Id. 75.

80 Id. 90 (Stewart, J., concurring). 
parental concurrence or that abortion in any event is in the minor's best interest. ${ }^{81}$

In such a case, the state would be furthering the constitutionally permissible end of encouraging pregnant minors to seek the help and advice of their parents in making the child-bearing decision. ${ }^{82}$

That Danforth does not absolutely foreclose the parents of minor children from participating in the abortion decision was also made clear in the companion case of Bellotti $v$. Baird. ${ }^{83}$ In that case the Court considered a Massachusetts statute that required parental consent to the abortion decision in most instances but also provided for judicial review in the event permission were denied. ${ }^{84}$ The Court unanimously vacated and remanded for certification to the Supreme Judicial Court of Massachusetts the question of the proper construction of the statute. Abstention was mandated because the statute was "susceptible of a construction by the state judiciary, "which might avoid in whole or in part the necessity for federal constitutional adjudication or at least materially change the nature of the problem." " 85 The Court stressed that it was "concerned with a statute directed toward minors, as to whom there are unquestionably greater risks of inability to give an informed consent." s8 The Court suggested that a statute requiring only parental consultation would materially change the nature of the problem encountered in Danforth. ${ }^{87}$

The scope of the substantive rights enjoyed by minors was further clarified in Carey v. Population Services International.ss

81 Id. $90-91$.

82 Id. 91.

83428 U.S. 132 (1976).

84 The statute provided in part that:

If one or both of the mother's parents refuse such consent, consent may be obtained by order of a judge of the superior court for good cause shown, after such hearing as he deems necessary.

Mass. Ann. Laws ch. 112, $\$ 12 p$ ( I) (Michie/Law. Co-op 1974).

85 Id. 147, quoting Harrison v. NAACP, 360 U.S. 167, 177 (1959).

86 Id.

87 Id. The Court hinted at a construction that would save the statute:

The picture thus painted by the respective appellants is of a statute that prefers parental consultation and consent, but that permits a mature minor capable of giving informed consent to obtain, without undue burden, an order permitting the abortion without parental consultation, and, further, permits even a minor incapable of giving informed consent to obtain an order without parental consultation where there is a showing that the abortion would be in her best interests. The statute, as thus read, would be fundamentally different from a statute that creates a "parental veto."

Id. 145 (footnote omitted).

88431 U.S. 678 (1977). 
In Carey the Court was faced with a challenge to a New York statute which, inter alia, prohibited the sale or distribution of contraceptives to minors under the age of sixteen. ${ }^{80}$ A plurality of the Court ${ }^{90}$ concluded that the right of privacy in connection with decisions affecting procreation, made applicable to minors in Danforth, included a right to be free from blanket prohibitions against distribution of contraceptives and thus declared the New York law unconstitutional. $^{21}$ In so doing, the plurality viewed Danforth as holding that the state could interfere with constitutional privacy rights of minors on a lesser showing than the compelling state interest test which is applied to the constitutional rights of adults, ${ }^{92}$ but that state restrictions "inhibiting privacy rights of minors are valid only if they serve 'any significant state interest . . . that is not present in the case of an adult." "93 The plurality suggested that

"[s]uch lessser scrutiny is appropriate [for regulation of the constitutional rights of minors] both because of the States' greater latitude to regulate the conduct of children ... and because the right of privacy implicated here is 'the

89 The statute also prohibited distribution of contraceptives to those over sixteen by anyone other than a licensed pharmacist, and additionally banned display of contraceptives. NEw York Education Law \$6811(8) (McKinney 1972).

90 Justice Brennan wrote the opinion and was joined by Justices Stewart, Marshall, and Blackmun in that portion relating to the right of minors to obtain contraceptives. Justices White, Powell, and Stevens, in separate opinions, concurred in the parts of the opinion concerning the other provisions of the statute, but concurred only in the result of the part of the opinion striking down the ban on distribution of contraceptives to minors.

Justice White based his concurrence primarily on the fact that the state had "not demonstrated that the prohibition against distribution of contraceptives to minors measurably contributes to the deterrent purposes which the State advances as justification for the restriction." 431 U.S. at 702 (White, J., concurring). Justice Powell's concurring opinion attacked the New York statute for infringing on the privacy interests of married females between the ages of fourteen and sixteen, and for prohibiting parents from distributing contraceptives to their children. Id. 707-08 (Powell, J., concurring). He indicated that a statute "requiring minors to seek parental guidance would be consistent with . . . prior cases." Id. 709. Justice Stevens concurred, but rather than stressing the constitutional right of the child to contraceptives, Stevens emphasized the interest of states in protecting young persons against the harmful consequences of unwise choices. Id. 714 (Stevens, J., concurring). Thus Justice Stevens found that a state could legitimately seek to protect minors from potentially harmful effects of sexual intercourse. What made the New York statute invalid as a protective measure, however, was the fact that it served to punish minors while protecting them. For by denying contraceptives to minors it exposed them to intolerably high risks of venereal disease. Id. 715.

Chief Justice Burger and Justice Rehnquist filed dissenting opinions.

91 Id. 691-98.

92 Id. $693 \&$ n.I5.

93 Id. 693, quoting Planned Parenthood v. Danforth, 428 U.S. 52, 75 (1976) (emphasis added). 
interest in independence in making certain kinds of important decisions' . . . and the law has generally regarded minors as having a lesser capability for making important decisions." 84

The conclusions reached by the Supreme Court in Danforth and Carey strongly suggest that minor, unemancipated children have constitutionally protected religious rights, distinct from the religious rights of their parents, that can be exercised independent of parental approval. This follows not only from the Court's ultimate recognition of substantive privacy rights that inure to children, but also from the mode of analysis used by the Court in arriving at its conclusions. Both Danforth and Carey established first that minors possess a constitutional right to privacy and then proceeded to delineate the scope of that right. Although both Carey and Danforth declared that the state need not show compelling reasons to validly inhibit minors' privacy rights, the statement that restrictions on these rights are "valid only if they serve [a] significant state interest . . . that is not present in the case of an adult" ${ }^{95}$ necessarily implies that the proper analysis of a minor's claim to a constitutional right must begin with a recognition that the minor enjoys the constitutional right in question. The state then must show that it has some "significant" interest arising from conditions related to childhood that provides constitutional justification for limitation of the right in question.

Carey thus declares that childhood is not a talisman that automatically justifies nullification of constitutional liberties; rather, if a state seeks to regulate the activities of children-activities which if engaged in by adults would be constitutionally protected-the state must point to some demonstrable characteristic of childhood that gives rise to a significant state interest in regulation beyond that which could constitutionally be imposed on adults. Danforth holds, moreover, that constitutional liberties possessed by children are, at least in part, rights that children can exercise independently of their

94 Id. 693 n.I5, citing Prince v. Massachusetts and Ginsberg v. New York. In Prince v. Massachusetts, 321 U.S. 158, 170 (1944), the Court stated "the power of the state to control the conduct of children reaches beyond the scope of its authority over adults. . . " See text accompanying notes 101-03 \& n.103 supra. Ginsberg v. New York, 390 U.S. 629 (1968), upheld the constitutionality of a New York statute prohibiting the sale of certain sexually explicit literature to children. Although this material was concededly not obscene for adults, the Court nevertheless allowed the state to ban the sale to juveniles, as to whom it was found to be obscene. See text accompanying note 58 supra.

95431 U.S. at 693, quoting Planned Parenthood v. Danforth, 428 U.S. 52, 75 (1976). 
parents and that cannot be delegated in a way that gives parents an arbitrary veto over these rights.

\section{Abortion v. Religion}

If Danforth and Carey suggest that children possess, albeit to a lesser extent, the constitutional rights of adults, they can not be said to establish a broad range of constitutional protection. The Court has been willing to find a right to privacy for minors encompassing their determination of questions raised by birth control and abortion; it might be less willing to find other rights. It seems prudent to ask, then, whether there is any justifiable distinction between the protected abortion decision and the as yet doubtful free exercise right.

Initially it can be argued that the reasons for extending free exercise rights to children are not as compelling as the justifications offered for extending rights to minors in the abortion context. The abortion decision is by its very nature a life decision which must be made immediately. It can affect the child's life for years to come, well into the time when the child becomes an adult. In this respect the decision can have grave affects on the child's adult life, and therefore the view that the child should be accorded the right to participate in the decision seems particularly compelling. In addition, the view that honors the minor's position on the abortion decision is consistent with the position that minors should be protected from shouldering certain adult responsibilities such as marriage, work and contractual obligations. ${ }^{96}$ When a minor requests an abortion over parental objection, the minor is often indicating that the child-bearing experience will be harmful to her development-that she is seeking to avoid the trauma and responsibility of an unwanted pregnancy. ${ }^{97}$ If the policy is that minors should be able to avoid duties that they would otherwise be obliged to fulfill, a parental right to veto the child's abortion decision is contrary to the law's policy, because it forces the minor to acquire the tremendous responsibility of nurturing a child.

It can be argued that none of these considerations apply with respect to the free exercise of religion. These decisions may not be life decisions, and can perhaps be postponed without causing significant harm until the child reaches the age of majority. Arguably,

90 See note 103 infra.

97 See Comment, The Validity of Parental Consent Statutes after Planned Parenthood. 54 U. DET. J. URB. L. 127, 144 (1976). 
these temporary limitations upon religious free expression do not represent permanent deprivations.

This argument is appealing to those with a completely secular outlook. Our secular culture is inclined to consider life crises, such as pregnancy and childbirth, to be more vital and immediate to a minor than her relationship with God. Even when the pregnancy is over, and the responsibility of raising an infant is avoided through adoption, it is undeniable that the psychological and social burden on the juvenile mother is severe. It is not surprising, however, that religious persons, adult or minor, would almost certainly disagree with this value judgment. Interference with religious conscience, observance, and expression strikes at the first and central value of the believer. God comes first, and the believer's relationship with his God can not be delayed, tempered, or ignored. The values reflected in any decision to offer the abortion decision greater protection than the religious decision are those of a society that has concluded that the religious decision does not really mean what it says it means.

Moreover, such a value judgment flys in the face of the ordering of the Constitution itself. The "privacy" right is nowhere mentioned, although now firmly, if only recently, established. The free exercise right is a first amendment right and lies at the heart of the most fundamental values of the Constitution's framers. For while abortion is primarily a matter of convenience, free exercise is a matter of conscience, and if the Constitution extends the former to any of our citizens, it is hard to believe it does not extend the latter.

But even if one is philosophically unconvinced that the value of free exercise is the equal of the privacy right to terminate a pregnancy, the immediacy and importance of the decision protected in Danforth are not, even by the most secular cost-benefit approach, greater than the immediacy and importance of certain religious decisions. Compare the impact on the minor in Danforth, if her parents were allowed to veto her abortion, with the impact on the children in Yoder if they rejected their parents religious views but were still denied an education pursuant to a state policy supporting the constitutionally protected parental decision. The former must endure a full pregnancy and bear the child; then she can presumably give it up for adoption. Although the social and psychological impact of this experience should not be underestimated, the impact on the Yoder child is surely greater if his religious views are subjugated, with the assistance of the state, to those of his parents. He must sacrifice, at least for a time, his education, and, not coinci- 
dentally, his chances for higher education and a professional career. True, he might "catch up," but this is unlikely at best, and involves at least as much pain as the Danforth minor would endure through a nine month pregnancy.

Finally the two rights, privacy and free exercise, are so closely related as to make any distinction here doubtful at best. The privacy concept ennunciated by the court in Griswold $v$. Connecticut, ${ }^{98}$ Roe $v$. Wade ${ }^{99}$ and in Meyers and Pierce is based on a right of personal autonomy in the making of certain fundamental choices which guide one's destiny-autonomy which is particularly important for young people in their developmental stage. The first amendment is premised on a belief that regimentation of mind and spirit blocks the advancement of knowledge and the discovery of truth; ${ }^{100}$ state regulation or state-sanctioned parental interference that intrudes on areas of belief and puts undue restrictions on spiritual development is inimical to these important developmental values. The rights protected by the first amendment are focused on the same values of individual autonomy and liberty that lie at the heart of the less specific right to privacy. A distinction between the two thus seems peculiar at best.

A second argument for denying juveniles independent religious rights despite Danforth and Carey is that minors lack the level of intellectual and emotional maturity that is prerequisite to the meaningful exercise of religious rights. ${ }^{101}$ Ginsberg $v$. New York, which

98381 U.S. 479 (1965).

99410 U.S. 113 (1973).

100 T. EMrerson, The Sxstem of Freedom of Exxhession 6-7 (1970).

101 There is now considerable evidence to the effect that adolescents possess the intellectual capacity necessary for the meaningful exercise of first amendment religious rights. During adolescence, children show "a widened capacity for abstract concept formation and for the ability to judge and reason." M. Pollard \& B. Geoghegan, The Growing Child in Contemporary Soctetx 298 (1969). This is due to the qualitative development of the adolescent's cognitive skills, which appears to begin around age eleven or twelve. See Piaget, The Intellectual Development of the Adolescent, in Adolescence: Psychological Perspectrves 22-24 (G. Caplan \& S. Lebovici eds. 1969). It is then that the "capacity of reasoning on hypotheses" begins, that is reasoning "on the basis of propositions, which are not taken as true or false, but are experimentally formulated in order to derive from them all possible consequences, which are then checked by comparison to the facts." Id. 23-24. For Piaget, this new ability to think abstractly and critically, and to judge in terms of values and past experiences is what enables the adolescent to "achieve his integration into the social relationships of adults." Id. at 25 . According to Elkind, this cognitive development is nearly complete by age sixteen, and the concept-forming and problem-solving abilities which the adolescent has developed remain with him throughout his life. See Elkind, Egocentrism in Adolescence, 38 Crend Dev. 1025, 1032 (1967).

As intellectual development progresses, and the child's ability to form abstract concepts and reason increases, he is also able to attain "mature and integrated moral behavior based on sound principles." M. Policaro \& B. Geoghegan, supra, 
allowed the state to ban the sale of certain literature to minors, recognized that in many situations minors are incapable of making rational, mature and informed decisions on crucial matters. ${ }^{102}$ Thus, states traditionally have age qualifications which restrict the fundamental right to vote, and which prohibit the sale of alcohol or tobacco to minors. Contracts entered into by a minor which legally obligate the minor are voidable, and minority is a disqualification from participation in certain types of employment and from performance of certain public functions. ${ }^{103}$ Therefore, when the state supports a parental right to make these decisions for the child, it is pursuing the constitutionally permissible end of protecting the minor from his own immaturity.

The problem with this argument, however, is that it was raised and rejected by the Court in Danforth, and there is no reason to believe that it would be any more compelling in a proceeding to determine the religious rights of a child. Indeed, although it is a

at 323. See generally Kohlberg, Moral Education in the Schools: A Developmental View, in StodIEs IN ADOLEscence 237 (R. Grinder ed. 1969).

Many psychologists believe that it is this development which leads to increased religious doubt and independent religious thought on the part of the adolescent. As one commentator has written:

Increased intelligence with the accompanying ability to reason motivates the adolescent to ponder over the religious beliefs he accepted so unquestioningly during childhood. With increased knowledge, especially that derived from scientific studies in school, the adolescent views his childish beliefs in a new light. Reasoning has been found to be the most important single cause for changing religious attitudes and revising childish religious beliefs.

E. Hurlock, Adolescent Deveropment 396 (1967). For many adolescents, this independent thinking leads to a period of religious doubt, which often manifests itself in the revision of religious beliefs. According to Hurlock,

[t]he adolescent should revise his religious concepts so that the beliefs based on them will be meaningful and useful to him as he grows older. Adolescents who are afraid to change their religious beliefs . . . because of threats from authoritarian parents ... will find themselves as adults in possession of religious beliefs that are no more in keeping with their new status than clothing styled for a child.

Id. at 403 (footnotes omitted).

On the other hand, some experts have argued that the child's future autonomy is best served by a general policy of state non-intervention in matters of parent-child decision making, thus guaranteeing him a stable and secure family environment where he will have the "opportunity on a continuing basis, not only to receive and return affection but also to express anger and to learn to manage his aggression ...." J. Goldstein, A. Freud, \& A. Solnit, Beyond the Best Interests of the Chido 5-6 (1973).

102 Ginsberg v. New York, 390 U.S. 629, 643 n.10 (1968).

103 See, e.g., 1 A. Conbin, Contracts $\$ 6$ (1963) (contracting restrictions); 1 The Chind and the State 315-57 (G. Abbot ed. 1938) (labor restrictions); Wisc. Stat. AnN. $\$ 602$ (West 1967); Pa. Const. art. 7, § 1; N.Y. Elec. Law $\$ 150$ (McKinney 1964) (voting restrictions); Wrsc. STAT. ANn. $\$ 176.30$ (West 1974); Pa. Cons. Stat. Ann. 47, \$4-493(1) (Purdon 1969); N.Y. Penar Law $\$ 260.20$ (McKinney 1967) (liquor restrictions). 
questionable value judgment to consider the abortion decision to be more "important" than religious decisions, it might be said to" require a greater level of maturity than the sort of decision that a child would usually desire to make in a dispute over his religious preferences. ${ }^{104}$ As Justice Stewart noted in his concurring opinion in Danforth, the decision to abort a pregnancy is "a grave decision, and a girl of tender years, under emotional stress, may be illequipped to make it without mature advice and emotional support." 105 Nevertheless, an independent privacy right of children was recognized, and no parental veto was allowed. If the maturity of the child passed muster in that context, it should hardly serve as a bar in the religious context.

Some courts have already recognized that adolescent children are sufficiently mature to meaningfully exercise the right to choose among competing religious beliefs. This is reflected in a number of decisions that have allowed children caught in the cross-fire of a custody dispute to make their own choice on the issue of religion. Thus in Hehman v. Hehman, a New York court ordered that a dispute between parents as to a child's religious upbringing be referred to an official referee, who would interview the thirteen-yearold boy to determine his own religious preference. ${ }^{100}$ The Court noted the boy's age and the fact that he had been exposed to both his parents creeds. ${ }^{107}$ Thus, the Hehman court concluded that the decision should be left to the child, who could not "be forced to enter a religion against his wishes." 108

A similar recognition of the competency of the child in these matters was recognized by the New Jersey courts in Boerger $v$. Boerger. ${ }^{109}$ In this case the appellate court gave approval to the trial court's decision to interview a ten-year-old child to ascertain her religious preference. The court stated that "[s]uch predilection,

104 One can, of course, posit a situation where a minor's free exercise of religion would endanger his life (such as refusal of medical treatment) or lead him away from the home. Both of these cases might warrant state intervention under the "significant state interest" test announced in Carey. See text accompanying notes 147-51 infra.

105 Planned Parenthood v. Danforth, 428 U.S. 52 (1976).

10813 Misc. 2d 318, 178 N.Y.S.2d 328 (Sup. Ct. 1958).

107 Id. at 321,178 N.Y.S.2d at 331.

108 Id. Earlier, the court of appeals had affirmed, per curiam, a lower court judgment that took a similar approach in resolving a parental dispute over the religious upbringing of a child. Martin v. Martin, 308 N.Y. 136, 123 N.E.2d 812 (1954).

10926 N.J. Super. 90, 97 A.2d 419 (1953). 
when ascertained, is a factor that will be considered by the trial court," in determining the religious issue in a custody dispute. ${ }^{110}$

In a more dramatic case, the Supreme Court of Pennsylvania recognized that children of sufficient age are often mature enough to make meaningful religious decisions. In In re Green, ${ }^{111}$ the Pennsylvania court was confronted with the question of whether the state could order a sixteen-year-old boy to submit to medical treatment over his mother's religiously based objection. The child was suffering from a curvature of the spine, which seriously impaired his physical well being, but did not threaten his life. ${ }^{112}$ The mother was a Jehovah's Witness who believed that the Bible proscribed the blood transfusions that would have been necessary had the surgery been undertaken. ${ }^{113}$ First the court ruled that "as between a parent and the state, the state does not have an interest of sufficient magnitude outweighing a parent's religious beliefs when the child's life is not immediately imperiled by his physical condition." 114 The court then remanded the case to the trial court for an evidentiary hearing to determine the preference of the boy-particularly the question whether he was a Jehovah's Witness-implying that if the child's religious views did not prohibit blood transfusions, then, perhaps, the state could order the surgery despite the mother's objections. ${ }^{115}$ Thus, the Supreme Court of Pennsylvania realized that, even in religious matters implicating important medical decisions, some minors are capable of making rational, meaningful decisions.

Given that the Supreme Court has recognized a children's right of privacy that to some extent protects a child's autonomy in making decisions about abortion, there is no sound reason to deny minors the right to free exercise of religion.

\section{Parent v. Child}

Recognition of an independent constitutional religious right for children should not, except in a narrow category of cases, ${ }^{116}$

$110 \mathrm{Id}$. at $103,97 \mathrm{A.2d}$ at 426.

111448 Pa. 338, 292 A.2d 387 (1972).

112 Id. at $340-41,292 \mathrm{~A} .2 \mathrm{~d}$ at 388.

113 Id.

114 Id. at 348,292 A.2d at 392 (emphasis in original).

115 Id.

116 The child's constitutional right is against state, not parental, interference. Parental rights are thus not likely to be diminished by recognition of the child's constitutional right unless the parent seeks state support in the control of the child. Thus any parental effort to enlist the state's aid in, for example, barring the child from school, may well be limited by the child's constitutional right. See notes 120, 121, 139 infra and accompanying text. 
conflict with the already established constitutionally protected right of parents to direct the religious upbringing of their children; for the child's religious right, found in the first and fourteenth amendments, is a right held only against government, not against individuals such as parents. ${ }^{117}$ Therefore, in most cases where parents, acting as private individuals, restrict their children's religious activities, no constitutional issues are involved. ${ }^{118}$ The recognition of a constitutionally recognized religious right of children does not give children a shield against purely parental intereference with their religious exercise; children will have to continue to rely on state protection of their religious interests as against their parents, and of course any state efforts to vindicate these interests are limited by the parental constitutional rights recognized in Pierce and Yoder. ${ }^{119}$ A case could arise if the state did seek to protect the religious rights of minors. This conflict would be between the child's state-supported interest in religious freedom (not the child's constitutional right) and the parents' constitutionally protected rights.

The parental religious rights recognized in Pierce and Yoder, however, are also rights against government, not against private individuals such as children. If parents seek state support in determining the religious upbringing of their children by asking for state assistance in restraining a rebellious child from exercising his religious beliefs in a way offensive to the parents, the state action would be limited by the child's constitutional religious rights. The resulting conflict would be between the parent's state-supported interest in parental religious control and the child's constitutional right. The recognition of constitutional religious rights of children

117 Private interference with use of state facilities raises potential constitutional questions. In United States v. Guest, 383 U.S. 745 (1966), six Justices were prepared to find that a racially-animated conspiracy to deprive blacks of equal use of state facilities was a federal crime under 18 U.S.C. $\$ 241$ (1970), a penal statute passed as an exercise of power granted to Congress under $\$ 5$ of the fourteenth amendment "to enforce, by appropriate legislation the provisions" of that amendment. Id. 761 (Clark, J., concurring, joined by Black, J. and Fortas, J.); id. 774 (Brennan, J., concurring and dissenting, joined by Warren, C.J. and Douglas, J.). Given Guest, private interference with the use of state facilities, such as schools or hospitals, is probably proscribable by Congress under $\$ 5$ of the fourteenth amendment. Thus, the argument could be made that one of the civil rights acts passed under the fourteenth amendment was intended to reach private interference with religious freedom. See, e.g., Action v. Gannon, 450 F.2d 1227 (8th Cir. 1971) (purely private conspiracy to interfere with religious services a violation of 42 U.S.C. $\$ 1985(3))$. See note 140 infra.

118 The state's involvement, however, need not be either exclusive or direct. See Burton v. Wilmington Parking Authority, 365 U.S. 715 (1961). Therefore, parents' sending their children to school under compulsion of state law would constitute state action as to the children even if the law did not seek to penalize the children for truancy. See also note 7 supra.

110 See text accompanying notes $37-54$ supra. 
does not conflict with parental constitutional rights. Except in the unusual case, ${ }^{120}$ the constitutional religious rights of children do not collide with constitutionally protected religious rights of others. ${ }^{121}$

That recognition of constitutional religious rights for children does not diminish constitutional parental rights does not méan, however, that this recognition will not to some extent reduce parental authority. The recognition of children's religious rights would be a constitutional restraint on the support the state can lend parents in restraining their children's religious activity. Moreover, as Danforth makes clear, state legislation delegating a child's religious decision-making to parents might be subject to constitutional attack. ${ }^{122}$

Arguably, this incidental reduction of parental autonomy will be desirable in most of the cases in which it occurs. The notion of a parental right to raise children is based on the premise that it will promote those goals society values in the upbringing of a child: physical, emotional, psychological and intellectual development. Where, however, the exercise of parental authority threatens to stifle the intellectual and moral development of the child, as might be the case if a parent constantly interferes with the child's religious beliefs and practices, it is reasonable to ask whether the state might not better serve the child's "best interests," and society's goals, by refusing to invoke legal sanctions in support of parental authority. When the parents "threaten the autonomous growth and expression of [family] members ..." ${ }^{123}$ there is no longer any sound reason to continue to support the family's authority. For at that point the family is interfering with the child's ability to develop individual autonomy and diversity of thought, the values underlying both the

120 If a state hospital offers medical aid to a child, and this treatment is contrary to the parents' religious tenets, the parents' constitutional rights are probably involved. $C f$. Doe v. Irwin, 428 F. Supp. 1198 (W.D. Mich.), vacated without opinion, 559 F.2d 1219 (6th Cir. 1977) (distribution of contraceptives by county health officials without parental consent violates parents' constitutional rights). If the hospital refuses to treat the child merely because of the parents' religious objections, this is an imposition upon the child of the parents' religious belief, constituting state action-or, more properly, inaction-arguably involving the child's constitutionally-protected free exercise right.

121 Therefore, in most cases the conflict will be between constitutional right and individual interest, cf. Gertz v. Welch, 418 U.S. 323 (1974) (first amendment right to free speech in conflict with individual's interest in personal reputation) rather than a conflict between constitutional rights, cf. Nebraska Press Ass'n v. Stuart, 427 U.S. 539 (1976) (conflict between first amendment freedom of the press and sixth amendment right to fair trial).

122 Planned Parenthood v. Danforth, 428 U.S. 52 (1976).

123 Tribe, supra note 7 , at 35 n.85. 
first amendment and the "best interest of the child" doctrine. Moreover, in most cases in which parents seek state support for their efforts to restrain their child's religious activities, the family is already in a state of breakdown and intervention on behalf of the parent to vindicate a notion of parental supremacy seems of little value. ${ }^{124}$

In the case where parental authority is presently joined with state action to prevent the child from exercising his religious rights in such a way as to palbably endanger his well being, the recognition of a religious right for children would not mean that the child would be allowed to injure himself irreparably. Danforth only proscribed the delegation to the parents of an arbitrary veto on the child's rights; the Court implied that the state retains a great deal of leeway in exercising authority over children. Therefore, consistent with Danforth, states may delegate some authority to the parents, or, in the proper case, offer them affirmative aid in controlling the activity of their children, even when constitutional liberties are involved. ${ }^{25}$ Carey, moreover, translates the Danforth implication into the formula that the state may proscribe constitutionallyprotected activities of children if it has "any significant state interest" in doing so "that is not present in the case of adults," ${ }^{126}$ a test that should be met in the case of a child posing a danger to himself which would result in irreparable harm.

\section{Developing A Workable Standard}

If children have constitutionally protected religious rights, an inquiry into their precise nature and scope is necessary. Particularly in those cases where the state is acting to support parental authority, and the interests of parents collide with the constitutional rights of children, a very sensitive balancing approach is required.

Precisely such a balancing was undertaken by the Court in Danforth and later clarified in Carey. The Court in Danforth

124 Some observers have argued that state intervention in parent-child matters should be limited to egregious cases of family breakdown. Too much intervention on behalf of either parent or child, they argue, will inevitably interfere with the family's ability to function as a socializing and educational tool, and as a mechanism which gives the child a sense of belonging and identity. Thus, Goldstein, Freud and Solnit have expressed their "preference for privacy": "[t]o safeguard the right of parents to raise their children as they see fit, free of government intrusion, except in cases of neglect and abandonment, is to safeguard each child's need for continuity." J. Goldstien, A. Freud, \& A. SolNTr, Beyond the Best Interests of THE CFID 7 (1973).

125428 U.S. at 72-75. See id. 91 (Stewart, J., concurring).

126431 U.S. at 693. 
struck down a statutory provision that completely removed the right from the child, but it left open the possibility that a state could adopt provisions that vested some limited decision-making authority in the parent. ${ }^{12 \pi}$ Justice Stewart suggested that a statute that in most cases required parental consultation or consent, but allowed the minor the right to establish that she was mature enough meaningfully to exercise her right, might well be constitutional. ${ }^{128}$

A religious free exercise right might take on similar characteristics. Given the state's traditionally greater latitude in regulating the conduct of children, ${ }^{129}$ the young child's lesser experience in making important decisions, ${ }^{130}$ and the fundamental interest of the parents in controlling the upbringing of children over whom they have custody, ${ }^{131}$ the child's right to free exercise would not always be preferred over the right of his adult parent to direct his upbringing. The underlying presumption might be that the course of religious action a child takes must be determined for the child by the parents early in the child's life; but as the child matures and approaches majority, he must be allowed to participate to an increasingly greater degree in the framing of the religious decisions that concern him. In each case the court would have to inquire as to the maturity of the child: age would be relevant, as would the child's emotional and intellectual capacity. This might require the judge to examine the child to determine whether he or she understands the nature of the proposed free exercise activity and its probable consequences. The court would also independently assess the character of the activities to determine whether engaging in them would threaten the child's health, safety or welfare. Finally, the court would have to assess the validity of the parental objection and the validity of the state's decision to vindicate the parents position.

To minimize the amount of judicial intervention, this inquiry should perhaps take on some objective characteristics. It has been strenuously argued that the law does not have "the capacity to supervise the delicately complex interpersonal bonds between parent and child," because it lacks "the capacity to deal on an individual basis with the consequences of its decisions [and] to act with the deliberate speed required by a child's sense of time essential to his

127428 U.S. at 75.

128 See id. at 91 (Stewart, J., concurring).

129 See Prince v. Massachusetts, 321 U.S. 158 (1944).

130 See generally Ginsberg v. New York, 390 U.S. 629 (1968).

131 See Wisconsin v. Yoder, 406 U.S. 205 (1972). 
well being." 132 Thus, the law "must limit the state to determining by some relatively objective standard who is entitled to decide, not what specific decision is to be preferred in a particular case nor whether a specific child has the 'wisdom' to make a choice." 133 Another argument in favor of developing objective criteria is that they would establish for each child, with some degree of certainty, the extent to which he enjoys constitutional rights and the situations in which these rights may be exercised. A degree of certainty is necessary if the various actors within the family unit are to perform their socially accepted roles:

Children have many special needs that must be met in their quest for maturity and independence. The most critical of these needs is a satisfactory and permanent psychological relationship with their parents. . . . If there is insecurity or lack of commitment in the relationship, either because of governmental intrusion or because a parent has substantial doubts about the extent of his other personal authority, serious psychological deficiencies are more likely to exist in the relationship. ${ }^{134}$

If objective criteria are developed by the courts, some semblance of certainty is maintained, even if the degree of certainty is less than that which exists where there is an irrebutable presumption in favor of parental authority.

Perhaps a specific age could be selected below which there would be a rebuttable but heavy presumption against religious free exercise. Sixteen has been suggested in the context of medical decisions, ${ }^{135}$ and might be applicable in the present context as well, although some religious free exercise decisions pose far fewer risks, and therefore demand a lower maturity level, than medical choices. In addition, there could be a presumption in favor of certain activi-

132 Goldstein, Medical Care for the Child at Risk: On State Supervention of Parental Autonomy, 86 YArE L.J. 645, 650 (1977). Goldstein continues:

The right to partial emancipation should not rest on satisfying on a caseby-case basis, some body of wise persons that the particular child is "mature enough" to choose or that the particular child's choice is "right". To introduce such a subjective process for decision would not be to emancipate the child but rather to transfer to the state the parental control and responsibility for determining when to consult and abide by the child's choice.

1d. 662-63 (footnotes omitted).

133 Id. 663.

134 Hafen, Children's Liberation and the New Egalitarianism: Some Reservations About Abandoning Youth to Their Rights, 1976 B.Y. L. REv. 605, 651. See also J. Goldstern, A. Freud \& A. Solntr, BeYond THE Best INTERests of the Cenco 13 (1973). 135 Goldstein, supra note 132 , at 663. 
ties and against others. Those free exercise choices that would free the child from the home might be disfavored given the strong social belief that optimal child development is best achieved when the parent-child relationship is maintained. Moreover, the lifelong effects of binding, childish choices made while outside the influence of the home may create permanent deprivations far more detrimental than the temporary limitations upon freedom inherent in a refusal to allow the child to completely sever ties. Where, however, the child's desire to leave the home is tearing the parent-child relationship apart, one might question whether maintaining the relationship under stress will really promote any of these socially desired goals. There might also be a presumption against religious free exercise choices within a medical context involving life or death. While recognizing that many minors have the capacity meaningfully to make some religious decisions, those that involve the ultimate decision whether to live or to die may be beyond the capacity of even the most mature minor. In addition, denying the minor this choice still leaves open a wide range of other choices and does not ultimately interfere with his freedom to explore new ideas-a value at the heart of the free expression guarantees. ${ }^{136}$

The above considerations help resolve some of the difficult questions left after Yoder and Danforth. Consider, for example, a fourteen-year-old child of Amish parents who desires to remain in school, claiming that he does not share his parents' Amish faith. The child attempts to attend school, but is prevented from entering by school administrators, who have been convinced by the parents that to educate the child contrary to the parents' religious belief constitutes state interference with rights recognized in Pierce and Yoder. The child sues to enjoin the school from preventing him from attending, asserting that the school is interfering with his first amendment religious rights by imposing upon him the religious practices of his parents. ${ }^{187}$ The child can couple this free exercise claim with an argument stressing the importance of education in maximizing his intellectual potential and future autonomy. ${ }^{138}$ The child's decision, though contrary to his parents' religious preferences, does not endanger his health, safety or welfare, and does not require him to leave the home. In addition, ordering the school

136 See text accompanying notes 98-100 supra.

137 It is just this kind of imposition that Justice Douglas wamed of in Yoder: "[I]f the parents in this case are allowed a religious exemption, the inevitable effect is to impose the parents' notions of religious duty upon their children." 406 U.S. $205,241-42$ (Douglas, J., dissenting in part).

138 See generally Knudsen, The Education of the Amish Child, 62 Cax. L. Rev. 1506 (1974). 
to admit the child does not interfere greatly with the constitutional rights of the parents. ${ }^{139}$ The court is not affirmatively decreeing anything with respect to the parents; it is simply preventing the public school from denying the child admittance based on the parents' religious preferences. The decree does not in any way compel the parents to do anything, and if the parents were adamant about the child's not attending, they could themselves restrain him from going to school, probably without implicating constitutional rights. ${ }^{140}$

A reversal of the above facts creates a more complicated dispute. Suppose that a fourteen-year-old child, in accordance with his religious beliefs, wishes to discontinue his schooling, over his parents' objections. If he refuses to attend school and is brought before a juvenile court judge as a truant, he can argue with force that the state would be penalizing the exercise of his constitutional

139 The alleged interference with parental rights in those cases in which the state merely offers the child a service, and does not in any way compel either parent or child to accept the services, see, e.g., Doe v. Irwin, 428 F. Supp. 1198 (W.D. Mich.), vacated without opinion, 559 F.2d 1219 (6th Cir. 1977), is certainly a more tenuous infringement upon those rights than the interference caused by laws compelling or restricting parental behavior. Indeed it could be argued that because the state's offer of services merely encourages a certain activity, without penalizing an alternative protected activity, there is no constitutional concern at all. $C f$. Maher v. Roe, 97 S. Ct. 2376 (I977) (state encouragement of childbirth, through funding, not infringement of right to abortion).

140 If the parents themselves were to physically restrain the child, the child might then be without a remedy. He could sue his parents under state tort law alleging that the parents were unlawfully restraining the child. But, a state court might well dismiss the complaint, if the state's tort laws have either never recognized children's suits against parents or have given the parents wide discretion. See W. Prossen, LAw OF TORTs 866-67 (1971). Faced with such an adjudication, the child would be forced to argue that the state, by refusing to extend tort law protection to him, is denying him equal protection of the law, reasoning that his parents could not have restrained an adult neighbor from attending school without becoming liable in tort. His claim would stand or fall on whether he could sustain a claim that such a classification based on his status as a minor-child is an impermissible one for equal protection purposes. See text accompanying notes 144-45 infra.

Alternatively, in his attempt to free himself from parental restraint, the child could assert that his right to free exercise of religion was held against private individuals as well as government. See Action v. Gannon, 450 F.2d 1227, 1234-35 (8th Cir. 1971) (holding that in passing 42 U.S.C. $\$ 1985$ (3) Congress was exercising its power under $\S 5$ of the fourteenth amendment and intended to prohibit purely private conspiracies to interfere with the free exercise of religion). See note 117 supra. This, though, is a controversial contention, not likely to prevail. Note also that when private individuals interfere with access to state facilities the state action analysis becomes particularly complicated. See United States v. Guest, 383 U.S. 745 (1966), discussed in note 117 supra.

Yet another approach has been suggested by Professor Tribe, who believes that a state's inaction with respect to the parental disciplinary measures is sometimes state action interfering with the child's constitutional rights: "[w] disintegration or at the threshold of collapse . . . then it seems wrong to exonerate the state of responsibility for such coercive parental measures as it permits even by its inaction." Tribe, supra note 7, at 12 n.13. 
religious rights by imposing truancy sanctions on him. Pitted against his position are the state's interest in educating its youth to assure their intellectual development and his parents' interest in controlling his upbringing. On the one hand, it seems that the gravity of the decision to end one's education, coupled with the parental control interest, is sufficiently "significant" to justify the interference with the child's rights under the Carey formula. ${ }^{141}$ But, if the existence of the religious right is premised on a belief in the ability of the child meaningfully to exercise it, then why should the child be denied free exercise on these facts, when a similar balancing in Yoder upheld the parent's free exercise rights? Of course, the case of a child's seeking a complete termination of his education is an extreme one. Imagine, then, a situation in which the child does not seek a total exemption from school, but rather an exemption once a week in order to observe a religious sabbath that falls on a weekday. In such a case, the possible effect of the limited absence on the child's overall welfare is more tenuous and his request for relief more compelling. If the request were made in good faith, it would seem to be one that should be respected.

As for the adolescent who refuses on religious grounds to attend the sectarian school in which his parents have enrolled him and is brought before a juvenile judge as an "incorrigible" child, the case turns on whether the parents can assert an interest strong enough to justify affirmative state intervention where the necessary effect is to hold the child in violation of a state statute for having done no more than to freely exercise his religious conscience. Where the child is an adolescent, and has not deserted the home, there seems to be no "significant" interest served by state intervention on the parents' behalf. The child remains willing to attend school-albeit not the one of his parents' choosing-and is not attempting to leave the home. Unless his actions are threatening his health or safety there seems to be no argument supportive of the state's right to become involved.

Where the child has left home entirely, either to join a religious sect of his own choosing or because of a disagreement with his parents about the religious viewpoints being imposed upon him, a very difficult case is presented. Here the parental interest in receiving state support is stronger, for the parent could argue that allowing the child's desertion would be a complete emasculation of the parental interest in participating in the child's upbringing. The state, moreover, could assert that the child's absence from home 
and from school will seriously impair his physical and mental health, and that a decision to leave the home requires a higher level of maturity than a child is presumed to have in cases involving less important decisions. Nevertheless, there may be instances in which the free exercise right of the child outweighs the parental and state interests even though leaving home is entailed. An example might be when the child is beyond the age of compulsory education and is willing to relinquish his claims to parental financial support. ${ }^{142}$

In a case in which the parents have chosen not to seek state assistance but to use self-help measures instead, the issue becomes whether the child can request that the state assist him in exercising his religion free from parental interference. Thus, if parents restrain a child from attending religious services that his parents find offensive, probably no constitutional issue is presented, and the child is left with whatever religious autonomy from his parents that the state has created. Regardless of the merits of his underlying claim, the child must show that the state is interferring with his rights; otherwise a constitutional issue does not arise. The child could argue that private interference with religious rights gives rise to a federal cause of action. This argument is without much force, however, because the federal civil rights statutes enacted under the thirteenth and fourteenth amendments probably cannot be invoked where the purely private interference is not racially motivated..$^{143}$ Alternatively, he could sue his parents under a state tort law alleging unlawful restraint, but it is difficult to see how the child's constitutional religious rights play any role in a case of parental self-help. If the state court dismissed the child's complaint because the tort law does not recognize the unlawful restraint claims of children against their parents, the child would have to argue that denying an unlawful restraint remedy against his parents, while routinely granting relief in other cases was a denial of the "equal protection" of the laws. He could argue that the state's classification of people to whom they will or will not grant relief in restraint cases works to interfere with the free exercise rights of children. The problem with this argument is that, under conventional state action analysis, failure of the state to intervene in a child's religious dispute with his parents does not constitute "state interference" with the minor's right to freely exercise his religious beliefs. ${ }^{144}$

142 See Tribe, supra note 7 , at 12 n.13.

143 See Runyon v. McCrary, 427 U.S. 160 (1976). See also Wisconsin Nat'1 Org. for Women v. Wisconsin, 417 F. Supp. 978 (42 U.S.C. \$ 1981 not applicable to sex discrimination). But see Action v. Gannon, 450 F.2d 1227 (8th Cir. 1971). 144 Cf. Maher v. Roe, 97 S. Ct. 2376 (1977) (refusal of state to fund abortion does not penalize privacy rights). 
Moreover, the state would argue that the classification of tort plaintiffs into two categories-(1) children bringing restraint cases against their parents and (2) all other plaintiffs-is a rational classification, established in part out of respect for parental constitutional rights. Because children are not a "suspect class," 145 this classification would probably be upheld, especially given the parents fundamental right that would become involved if the state intervened. This does not mean, of course, that state courts or state legislatures could not, if they chose, protect children's right to free exercise of religion against unreasonable parental restraint. The state interest in insuring mature children the right to attend religious services of their choice is probably sufficient to overcome the parental rights recognized in Pierce and Yoder. ${ }^{146}$ Certainly the state interest would override any parental child-rearing right in the case of extreme forms of restraint or cruelty. But the delineation of the scope which the religious rights of children should be accorded by the state is beyond the scope of this Comment.

- The medical cases present interesting problems. One possible case is raised if the child has been refused treatment at a hospital because his parents, for religious reasons, have failed to give the consent required by state law. ${ }^{147}$ The child sues, seeking to enjoin the hospital from denying him admittance, on the ground that the state, through its parental consent requirement, is forcing him to live according to the religious beliefs of his parents. If the child is sufficiently mature to understand the possible benefits and risks of the surgery, ${ }^{148}$ and if the statute delegates to his parents a "religious veto" over the medical treatment, it probably impermissibly infringes upon his first amendment rights. Here the parents certainly have an interest in the child's adherence to their religious faith and may also have an interest in guarding against any treatment that might increase their liability for the support and mainte-

145 See San Antonio Ind. School Dist. v. Rodriguez, 411 U.S. 1 (1973).

146 The Yoder Court expressly did not confront such a situation. 406 U.S. at 232. See also notes 4 \& 5 supra.

147 In most jurisdictions, minor children are considered incapable of consenting to surgical care and the invasion of the person of the child by a physician will be a technical battery unless the consent of the parent has been received. See Bonner v. Moran, 126 F.2d 121 (D.C. Cir. 1941) (15 year-old child); Zoski v. Gaines, 271 Mich. 1, 260 N.W. 99 (1935) (9\% year-old child); PA. Star. AnN. tit. 35, $\$$ 10101-10105 (Purdon 1977); Mo. ANN. STAт. \$431.061 (Vernon Cum. Supp. 1977). But see Lacey v. Laird, 166 Ohio 12, 139 N.E.2d 25 (18 year-old child).

148 Some courts have reasoned that some minors are sufficiently mature to give effective consent to medical treatment. See W. ProssEn, LAW OF Torss 103 n.51 (1971). 
nance of the child.149 But where the balance of benefit and harm favor surgery and the child seems sufficiently mature to understand the balance, his request that the application of the consent statute be enjoined should be granted.

An equally difficult case is presented where a minor who belongs to a religious sect that prohibits medical treatment, sues to enjoin a state hospital from going ahead with surgery that his parents want him to have. If the surgery is aimed at correcting a condition that is arguably interfering with the child's ability to lead a "normal" lifestyle, but is not threatening his life, there is a strong case for vindicating the child's religious rights, especially if the child is not only sufficiently mature meaningfully to exercise the religious belief, but is also able to appreciate the serious consequences of his medical decision. Despite the fact that the parental interest in making these decisions is strong, when the decision to be made concerns surgery to correct a defect which is not life threatening, the issue is much akin to a lifestyle choice, and the child's autonomy should be respected. ${ }^{150}$ Where, however, the failure to provide surgical care entails the likelihood of death, the child's case is weakest. In such an instance there is authority for the proposition that, even if an adult were asserting the religiously-based objection, the state's interest in the preservation of human life justifies a court order for compulsory treatment. ${ }^{151}$ The condition of infancy only strengthens the case for overriding the child's religious rights. Not only does the state have an interest in protecting life, but, in this case, the parents' interest in the upbringing of the child is completely negated if the child is allowed to choose to die. Of course, this discussion presupposes that the risk of death from surgery is less than the risk of death if treatment is foregone. Where, however, the proposed treatment itself poses a great risk of death, the case for vindicating the child's rights is stronger.

Finally, there are the custody cases. If the court includes in the decree a provision dealing with the religious upbringing of the child, it should follow the guide of the New York and New Jersey courts, ${ }^{152}$ which inquire into, and often give effect to, the preference of a mature child. The recognition of first amendment religious rights for minors would call for at least this type of inquiry.

149 See Lacey v. Laird, 166 Ohio 12, 139 N.E.2d 25 (1956), noted in 10 VAND. L. REv. 619 (1957).

150 See Goldstein, supra note 132, at 664.

151 See Application of President \& Directors of Georgetown College, Inc., 331 F.2d 1000 (D.C. Cir.), cert. denied, 377 U.S. 978 (1964).

162 See text accompanying notes 106-10 supra. 


\section{Conclusion}

This Comment has examined the extent to which minors enjoy the guarantees of the first amendment's free exercise clause independent of their parents. With particular emphasis on those instances in which a child's religious preferences run contrary to those of the parent, it has examined the evolution of parental authority in these matters, and the developing recognition of independent children's rights. With the guidance of the Supreme Court's decisions in Danforth and Carey, it has suggested that, in a proper proceeding, the Supreme Court would now recognize that children enjoy some right to determine the character of their religious upbringing. That right would necessarily be a qualified one, subject to state interference and state-sanctioned parental interference on a lesser showing than would be required to justify interference with the religious rights of adults. But it would be a recognized right nonetheless.

In determining the scope of the right, and its application in particular cases, it has been suggested that the courts would have to look to the totality of the circumstances that underlie the minor's claim, including age, maturity level, and the character of the proposed religious exercise, in addition to the basis for any state or parental objection. When an older, more mature child is concerned, the presumption would favor his free exercise; the presumption would be reversed in the case of a younger, less mature minor.

The growing emphasis on protecting children's rights, both in the procedural and substantive arena, makes it likely that courts will be presented with issues implicating children's religious liberty; it is hoped that courts will afford these rights the constitutional respect they deserve by not summarily disregarding them merely because they are asserted by children. 